\title{
Proses Dekolonisasi Republik Demokratik Timor-Leste dan Keterlibatan Indonesia
}

\section{Syahbuddin}

STKIP Taman Siswa Bima

syahbuddin07@gmail.com

Artikel Info

Tanggal Publikasi

2020-12-15

\section{Kata Kunci}

Dekolonisasi

Keteribatan

Indonesia

\section{Abstrak}

Tulisan ini bertujuan untuk mendeskripsikan proses dekolonisasi Timor Portugis dan latarbelakang keterlibatan Indonesia dalam proses dekolonisasi tersebut. Penelitian ini menggunakan pendekatan kualitatif dengan metode penelitian sejarah. Metode penelitian sejarah terdiri dari empat langkah yaitu pengumpulan data heuristik, kritik sumber atau verifikasi, analisis atau interpretasi dan penulisan sejarah atau histiriografi. Hasil penelitian menyimpulkan bahwa proses dekolonisasi Timur Portugis dilatarbelakangi meletusnya revolusi di Portugal pada tanggal 25 April 1974 yang dikenal dengan Revolusi Bunga "Carnation Revolution" atau "Revolusi Anyelir". Paska kudeta terjadi perbedaan pandangan tentang konsep dekolonisasi terhadap kononikoloni Portugis baik di Afrika maupun di Asia. Perbedaan pendapat tersebut menyebabkan tidak adanya kesatuan dan kejelasan konsep tentang proses dekolonisasi di Timor Portugis. Hal ini menyebabkan kekacauan di Timor Portugis yang diwarnai persaingan politik dan senjata antara partai-partai. Keterlibatan Indonesia dalam proses dekolonisasi di Timor Portugis latarbelakangi oleh dua faktor: (a) kondisi politik internasional dimana sedang berlangsung perang dingin antara blok Barat dengan blok Timur. Paska kemenangan komunis di Vietnam, negara-negara Barat mengkhawatirkan Timor Portugis akan mendapat pengaruh dari Cina maupun Uni Soviet. Oleh karena itu bangsa-bangsa Barat mendorong Indonesia mengambil-alih Timor Portugis; (b) adanya keinginan partai politik di Timor Portugis untuk berintegrasi dengan Indonesia. Apodeti merupakan "pintu" bagi Indonesia untuk terlibat dalam masalah Timor Portugis dan pintu itu semakin terbuka dengan adanya deklarasi Balibo pada tanggal 30 November 1975 untuk berintegrasi dengan Indonesia; (c) aspek geografis, Indonesia berbatasan langsung dengan Timor Portugis. Indonesia juga membutuhkan stabilitas kawasan dalam rangka pembangunan.

\section{Pendahuluan}

Republik Demokratik Timor-Leste telah melalui perjalanan sejarah yang cukup panjang. Sejak tahun 1702, Republik Demokratik Timor-Leste merupakan daerah koloni Portugis yang ditandai dengan keberhasilan membangun kekuasaan di Lifau di bawah gubernur Antonio Coelho Guerreiro. Oxford English Dictionary (OED), kata kolonialisme berasal dari kata Latin/Romawi 'colonia' yang berarti 'tanah pertanian' atau 'pemukiman', dan mengacu kepada orang-orang Romawi yang bermukim di negeri-negeri lain tetapi masih mempertahankan kewarganegaraan mereka. Kolonialisme yang secara etimologis tidak mengandung arti penjajahan, melainkan hanya semacam wilayah atau perkampungan, mempunyai konotasi negatif sesudah terjadinya interaksi yang tidak seimbang antara pendatang baru dengan penduduk lama (Ratna, 2008: 20). Kolonialisme adalah paham tentang penguasaan oleh suatu negara atau bangsa lain dengan maksud untuk memperluas negara itu. (https://kbbi.web.id/kolonialisme, diunduh 3 Maret 2020 jam 11.11).

Kolonialime Portugis diawali dengan penjelajahan samudera oleh Colombus. Menurut (Nugroho, 2016)., Raja Portugis, Henry, meyakini bahwa cara untuk mendapat laba maksimum adalah dengan mem-by pass perdagangan muslim-Italia tersebut. Akhirnya ia memerintahkan eksplorasi untuk 
mendapatkan dominasi perdagangan dan emas sampai ke sekitar Afrika (Miftakhuddin, 2019: 24). Penerus Henry, Raja John II, berkeinginan untuk menguasai jalur perdagangan di Asia. Maka John II mengirim Bartholomew Diaz yang hanya sampai di Afrika yaitu tanjung badai yang oleh raja diganti namanya dengan Tanjung Harapan (Cape of Good Hope). Penjelajah selanjutnya yaitu Vasco da Gama yang sampai di Calicut pada 1498 yang dilanjutkan denga dibangunnya pos perdagangan.

Setelah menguasai Malaka 1511, Portugis memulai masa kolonialnya melalui perdagangan langsung dan terbuka dengan penghasil rempah lain, seperti; Ternate, Banda, Seram, Ambon, dan Timor sembari memperluas kekuasaannya ke Maluku. Informasi tentang pulau Timor dan Solor dalam Summa Oriental bahwa kedua pulau itu penghasil kayu cendana, maka upaya penguasaan terhadap kedua pulau itu mulai dirintis yang kemudian berhasil dicapai pada tahun 1681 .

Kolonialisme Portugis berakhir pada tahun 1975, yang ditandai dengan dilancarkannya Operasi Seroja pada 7 Desember 1975. Meletusnya revolusi Bunga tahun 1974 telah membawa perubahan kebijakan Portugis terhadap koloni-koloni mereka baik di Asia maupun Afrika. Seiring dengan situasi global yang ditandai dengan perang dingin antara blok Barat dan blok Timur serta keterlibatan Indonesia telah memberikan warna tersendiri terhadap proses dekolonisasi Timor Portugis.

Pada mulanya Indonesia tidak memiliki ambisi teriotorial terhadap Timor Portugis dan hal itu disampaikan pertama kali diumumkan setelah sidang Dewan Stabilisasi Politik dan Keamanan yang diadakan pada tanggal 8 Oktober 1974. Indonesia mengklaim bahwa wilayahnya adalah bekas jajahan Belanda termasuk Irian Jaya sekarang. Hal menarik disini, Indonesia pada akhirnya melibatkan diri dalam proses ini dan kemudian menempatkan Timor Portugis di bawah Negara Kesatuan Republik Indonesia sebagai propinsi ke-27 dengan nama Timor-Timur.

\section{Metode Penelitian}

Penelitian ini menggunakan pendekatan kualitatif dengan metode penelitian sejarah. Garragham (1975) menjelaskan metode penelitian sejarah adalah seperangkat aturan dan prinsip untuk mengumpulkan sumber-sumber sejarah secara efektif, menilainya secara kritis dan mengajukan sistensis dari hasil-hasil yang dicapai dalam bentuk tertulis (Abdurrahman, 2007:53). Metode penelitian sejarah terdiri dari empat langkah yaitu pengumpulan data heuristik, kritik sumber atau verifikasi, analisis atau interpretasi dan penulisan sejarah atau histiriografi.

Pengumpulan data/heuristik menggunakan teknik studi dokumen. Dokumen merupakan catatan peristiwa yang sudah berlalu (Sugiono, 2013: 329). Data-data ini dapat diperoleh dari buku, jurnal, karya ilmiah, ensiklopedia, internet dan sumber lainnya. Tahap kedua adalah kritik sumber (verifikasi) yaitu menyaring secara kritis terutama terhadap sumber-sumber pertama agar terjaring fakta yang menjadi pilihan (Sjamsuddin, 2007: 131)

Tahap ketiga adalah analisis data atau interpretasi berarti menafsirkan atau memberi makna kepada fakta-fakta atau bukti-bukti sejarah (Daliman, 2012:83). Interpretasi sejarah menggunakan dua metode yaitu analisis dan sintesis. Analisis yaitu menguraikanfakta-fakta sejarah, sedangkan sintesis berarti menyatukan/menggabungkan. Analisis adalah usaha sistematis untuk mengkaji suatu problem dengan melihat unsur-unsur, menguraikannya dalam beberapa komponen atau bagian (Daliman, 2012: 90). Tahap keempat adalah historiofrafi adalah proses penyusunan fakta sejarah dan berbagai sumber yang telah diseleksi dalam bentuk tulisan sejarah (Sulasman, 2014: 147).

\section{Hasil dan Pembahasan}

\section{Kedatangan Portugis di Pulau Timor}

Portugis merupakan salah satu negara pelopor penjelajahan saumudera yang berani. Beberapa penjelajah Protugis yang termasyur antara lain Bartholomeu Diaz, Vasco da Gama dan Alfonso de 
Albuquerque. Penjelajah terakhir yang berhasil menguasai Malaka pada tahun 1511 dan setahun kemudian mengirim eskpedisi yang dipimpin Fransisco Serao ke Maluku sebagai gudang rempahrempah. Informasi tentang Pulau Timor diceritakan oleh Tome Pires dalam Summa Oriental sebagai berikut: Kedua pulau ini (Solor dan Timor) menghasilkan cendana putih yang melimpah (Pires, 2014: 283). Berita tentang pulau Timor juga datang dari Duarte Barbosa mengatakan bahwa pulau ini dikunjungi oleh kapal dari tanah Arab dan Jawa untuk mengambil kayu cendana. Sedangkan berita Pigafetta (1522) menyebut bahwa pada waktu mereka (yaitu kapal Spanyol sisa dari ekspedisi Magellan) singgah di pantai utara Timor, sebuah kapal dari Luson (kepulauan Filipina) sedang berlabuh di tempat itu, rupanya juga dalam rangka perdagangan kayu cendana (Lapian dan Chaniago, 1988: 10). Berdasarkan keterangan di atas bahwa kayu cendana merupakan komoditi perdagangan yang penting pada saat itu dan pulau Timor merupakan jaringan perdagangan yang berpusat di Jawa Timur, Celebes (Sulawesi), dan memiliki kaitan dengan jaringan komersil di Arab.

Satelah Portugis, bangsa-bangsa Barat lainnya seperti Spanyol, Belanda dan Inggris yang semuanya bersaing untuk mendapatkan rempah-rempah. Namun Portugis kalah bersaing dengan pedagang-pedagang lainnya di Nusantara terutama Belanda (VOC). Belanda memiliki modal besar yang disediakan pemerintah yang memungkinkan VOC maju lebih dulu dibandingkan dengan lawannya seperti Inggris dan Spanyol. Dengan modal besar, VOC mampu membiayai operasi-operasi militer dan berhasil mengusir Portugis di Malaka tahun 1641. Dengan demikian salah satu faktor yang mendorong kolonialisme Portugis di pulau Timor adalah desakan Belanda yang telah menguasai hampir seluruh wilayah Nusantara sehingga menutup kesempatan bagi Portugis untuk mengembangkan wilayah kekuasaannya kecuali di pulau Timor. Portugis harus meninggalkan kemegahan Malaka sebagai urat nadi perdagangan nusantara pada saat itu. Portugis kemudian menuju Pulau Timor. Eksistensi Portugis di pulau Timor diketahui sejak tahun 1590 dimana mereka membangun gereja Katholik pertama di Lifau (Oecusse) (Thomaz, 1994: 598).

Sejak tahun 1642, Portugis mulai melakukan penaklukan beberapa kerajaan di pulau Timor. Hasilnya tahun 1681 daerah Solor dan Timor secara resmi dinyatakan sebagai bagian dari Estado da India, yaitu daerah kekuasaan kerajaan Portugal di kawasan Asia dengan ibukota di Goa (Lapian dan Chaniago, 1988: 14). Portugis kemudian mengangkat Antonio Coelho Guerreiro pada tahun 1702 sebagai gubernur Timor Portugis dengan demikian praktek kolonialisme resmi dimulai. Kehadiran Portugis pada 1702 pada awalnya tidak begitu banyak mempengaruhi keadaan sosial dan ekonomi penduduk asli Timor Portugis, hal ini disebabkan pusat koloni Portugal di Asia Timur terletak di Goa. Timor Portugis hanya dijadikan sebagai pos perdagangan. Namun kedudukan Portugis di Lifau tidak bertahan lama, keberadaan Belanda di Kupang berhasil mengusir Portugis untuk pindah ke Dili pada tahun 1769.

Setelah terjadi konflik selama berabad-abad dengan Belanda, pada tahun 1859 kedua belah pihak menetapkan wilayah kekuasaan dan perbatasan masing-masing daerah koloni. Penetapan perbatasan itu baru ditandatangani pada tahun 1915 oleh kedua belah pihak setelah diputuskan dalam Sentenca Arbital, mahkamah internasional di Den Haag.

Di Dili, Portugis mendapat resistensi dari penguasa lokal, tahun 1779 pecah perlawanan terhadap Portugis di bawah pimpinan raja Luca yang dipandang sebagai Ratu Adil sehingga mendapat dukungan dari raja-raja lain untuk melawan Portugis. Mereka berkeyakinan bahwa roh nenek moyang mereka akan membantunya untuk mengusir Portugis. Dukungan terhadap raja Luca menurut Weber (1920) merupakan hal yang logis. Para Liurai tentu memliki kharisma sebagai mutu tertentu yang melekat pada kepribadian seseorang yang menyebabkan ia dianggap luar biasa dan diperlakukan orang sebagai seseorang yang mempunyai kekuatan supranatural (gaib), seorang manusia super atau setidak-tidaknya mempunyai kekuatan atau kualitas sangat istimewa (Burke, 2011: 133). Pemerintah Portugis 
mengadakan serangan balasan dan berhasil menumpas perlawanan ini yang berlarut sampai 1785 (Lapian dan Chaniago, 1988: 16).

Paska Kongres Wina pada tahun 1815, Belanda dan Portugis kembali ke wilayah jajahannya masing-masing, Belanda menguasai Kupang sedangkan Portugis menguasai Dili. Portugis membangun kekuasaannya di Dili hampir sama dengan pola Belanda terhadap raja-raja di Jawa. Portugis menjalankan pemerintahan tidak langsung tetapi melalui Liurai dan sebagai imbalannya mereka mendapat otonomi di daerahnya masing-masing. Di samping itu, Portugis juga memanfaatkan persetaruan di antara mereka dengan melaksanakan politik adu domba.

Kota Dili mulai dibangun pada tahun 1834, namun kondisinya digambarkan oleh Alfred Russel Wallace, naturalis, ilmuwan dan geografer masyhur, menulis pada 1861 bahwa Dili, 'tempat paling miskin bahkan sekalipun dibandingkan kota-kota termiskin di Hindia Belanda... tak ada tanda-tanda orang bercocok-tanam atau peradaban di sekitarnya' (Wallace, 1869: 144-145). Selanjutnya dijelaskan bahwa 'pemerintahan Portugis di Timor merupakan salah satu yang paling telengas. Tiada seorang pun yang setidaknya peduli pada perbaikan negeri tersebut, dan pada saat ini, setelah tigaratus tahun pendudukan, tiada satu mil jalan yang meretas kota, dan tak ada seorang penduduk Eropa yang bermukim sendirian di manapun' (Wallace, 1869: 151). Portugis juga melakukan kegiatan penginjilan yang dilakukan oleh padri Dominikan. Di kota Dili misalnya, pada tahun 1856 telah berpenduduk sekitar 3.000 jiwa, di antaranya sebanyak 2.047 jiwa sudah beragama Katolik.

Pada masa pemerintahan gubernur Celestino da Silva (1894-1908), Portugis menghadapi perlawanan yang paling besar sepanjang kedatangannya di Timor Portugis. Perlawanan terbesar dilancarkan oleh Dom Boaventura dari Manufahi pada tahun 1911. Pihak Portugis mengerahkan pasukan tentara Liurai yang amat besar yang berjumlah 12.000, serta mendatangkan pasukan dari Mozambique sehingga berhasil menumpas perlawanan ini pada tahun 1912. Setelah perlawanan dapat dipatahkan semua, kedudukan para raja sesudah itu berubah sama sekali. Dengan menerima piagam pengangkatan (Carta Patente) mereka diakui oleh pemerintah kolonial sebagai kepala dengan wewenang tertentu, jadi mereka sebenarnya sudah menjadi pejabat pemerintah sipil Portugis (Lapian dan Chaniago, 1988: 20). Sedangkan kepada desa (Suco), Portugis memberikan kewenangan langsung sebagai pemerintahan lokal. Kebijakan ini bertujuan mengurangi dan memotong kewenangan dan pengaruh Liurai dan menetapkan kontrol Portugis yang lebih langsung terhadap semua daerah di pedalaman Timor Portugis.

Portugis kini memasuki masa asimiliasi terhadap koloninya di Timor Portugis. Antonio de Oliveira Salazar pada tahun 1926 mempertegas bahwa Timor Portugis sebagai daerah jajahan dimana penduduk pribumi dibagi dua yaitu antara masyarakat civilizado (beradab) dan nao-civilizado (belum beradab) (Lapian dan Chaniago, 1988: 21). Masyarakat beradab menurut Portugis adalah mereka yang menurut 'politik asimilasi' telah mencapai tingkat Civilizacao Portuguesa, dan untuk mencapai tingkat demikian mereka harus mengikuti sistem pendidikan Portugis yang menanamkan nilai-nilai kebudayaan Portugis.

Proses asimilasi masyarakat Timor Portugis dilaksanakan melalui pendidikan dimana Portugis membangun sekolah sejak tahun 1915 dengan membuka Pendidikan Dasar dan baru tahun 1952 didirikan Sekolah Tingkat Menengah, Pendidikan Seminario tahun 1954 dan Sekolah Kejuruan pada tahun 1956. Asimilasi juga dilalui dengan penyebaran agama Katolik, urbanisasi dan ekonomi dengan terbentuknya Wilayah Ekonorni Nasional tahun 1953.

Penderitaan rakyat Timor Portugis berlanjut dengan pecahnya Perang Dunia II yang ditandai dengan penyerangan Jepang terhadap pangkalan Angkatan Laut AS di Pearl Harbour pada 7 Desember 1941. Untuk menahan gempuran Jepang terhadap Australia, pasukan Inggris, Australia dan Belanda mendarat di Timor Portugis pada 17 Desember 1941. Dampak perang tersebut terhadap rakyat Timor 
sungguh membinasakan. Sekitar 40.000-60.000 penduduk Timor dilaporkan meninggal (Dunn, 2003: 19-22). Kebanyakan aksi Jepang karena kecurigaan mereka pada Timor Portugis membantu pasukan Australia dalam melawan gempuran pasukan Jepang. Setelah mengalahkan Sekutu, Jepang menerapkan Romusha (kerja paksa) kepada semua rakyat untuk membuat jalan yang menghubungkan kota Dili dengan tiga belas Kabupaten yang ada di Timor Portugis.

Setelah perang selesai dengan kemenangan pihak Sekutu, Portugis kembali menguasai Timur Portugis. Pulihnya kekuasaan Portugis disebabkan karena keberhasilan polisi rahasia Portugis Polícia Internacionale de Defesa do Estado (PIDE). Salazar menempatkan polisi rahasia di Dili untuk memonitor kegiatan Indonesia dan sentimen anti Portugis (Nicol, 1978: 21). Faktor lain adalah kegagalan kaum terdidik (cendekiawan) Timor Portugis. Mereka tidak seperti para cendekiawan di koloni-koloni Belanda dan Inggris. Para cendekiawan di koloni Belanda misalnya Soekartno dan Hatta berhasil memanfaatkan kekosongan kekuasaan untuk memproklamirkan kemerdekaannya tanpa menunggu persetujuan Jepang maupun Belanda yang kembali paska perang.

\section{Proses Dekolonisasi Timor Portugis}

Paska Perang Dunia II pandangan dunia internasional terhadap praktek kolonoalisme mulai berubah dengan dikeluarkannya Piagam PBB tahun 1945. Isi piagam PBB kemudian ditegaskan kembali dalam Sidang Umum PBB tahun 1960 bahwa penjajahan sebagai pengingkaran atas hak asasi manusia. Antonio de Oliveira Salazar yang tampil sebagai Perdana Menteri Portugal tahun 1951 tidak luput dari tekanan dunia internasional terkait dengan tuntutan Piagam PBB. Menanggapi kesepakatan internasional yang semakin berkembang mengenai pentingnya dekolonisasi ini, Portugis merubah penyebutan wilayah-wilayah jajahannya sebagai "provinsi seberang lautan" pada tahun 1951. Baru pada tahun 1955 Timor Portugis secara resmi berubah status menjadi Propinsi Luar Negeri atau Propinsi Seberang Laut.

Memasuki tahun 1960 Portugis dihadapkan dengan gerakan kemerdekaan di daerah-daerah koloni di Afrika. Oleh karena itu Portugis harus mengeluarkan biaya yang besar untuk membiayai perang tersebut. Kondisi ini diperparah dengan bergabungnya Portugis dengan Asosiasi Perdagangan Bebas Eropa tahun 1961, dampaknya para pengusaha tidak lagi mencurahkan perhatiannya terhadap kononi mereka di Afrika maupun di Timor Portugis. Masalah ekonomi dan politik di atas menyebakan Salasar jatuh dan digantikan oleh Marcello das Neves Alves Caetano (1968-1974). Naiknya Caetano ternyata tidak mampu merubah kondisi yang ada.

Kondisi di atas menimbulkan ketidapuasan di kalangan perwira militer yang bergabung dalam Movimento das Forças Armadas (MFA) yang didirikan pada 5 Maret 1974 dan dipimpin oleh Jenderal António Sebastião Ribeiro de Spínola. Para tentara merasa tidak puas dengan penderitaan yang dialami selama dinas kemiliteran di Afrika, mereka memaksa para politisi untuk melakukan suatu perubahan radikal dalam sistem politik di Portugal yang lebih manusiawi menurut kehendak kelompok kiri (komunis) yang pada saat itu menguasai percaturan politik dalam negeri Portugal (Araujo, 2014: 8).

Peristiwa di atas terjadi tanggal 25 April 1974 yang dikenal dengan Revolusi Bunga "Carnation Revolution" atau "Revolusi Anyelir" (dalam bahasa Portugis "Revolução dos Cravos") karena revolusi ini berjalan damai tanpa ada pertumpahan darah dan selama demonstrasi massa menaruh bunga anyelir di moncong senapan tentara yang menghadang sebagai simbol perdamaian. Setelah kekuasaan diambil alih oleh MFA, Portugal mulai membuka peluang kepada wilayah jajahannya dalam hal ini termasuk Timor Portugis untuk memulai proses dekolonisasi.

António Sebastião Ribeiro de Spínola diangkat menjadi Presiden oleh Movemento Forcas Armadas (MFA) dengan dua program politiknya yaitu gagasan tentang demokratisasi dan dekolonisasi (Neonbasu, 1997: 40). Spínola mengusulkan program dekolonisasi untuk wilayah-wilayah jajahannya. Menurut Spinola, dekolonisasi pada dasarnya adalah usaha pembentukan negara federal yang masing- 
masing memiliki otonomi intern secara penuh, sedangkan pemerintah federal di Lisabon akan menguasai pertahanan dan hubungan luar negeri (Soekanto, 1976: 71). Solusi federal Spínola tidak memperoleh dukungan yang luas, bahkan dalam tubuh MFA sendiri makin melemah. Opini publik menghendaki agar Portugis mundur dari semua wilayah jajahan mereka baik di Afrika maupun Asia.

Pergeseran kebijakan ini berbuntut dengan pengunduran diri Spínola pada bulan September 1974 dan digantikan oleh Jenderal Fransisco da Costa Gomes sebagai Presiden, dan Brigjen Vasco Goncalves sebagai perdana menteri. Perbedaan pendapat ini melahirkan polarisasi politik nasional Portugal yang semakin tidak menentu arahnya. Namun pada akhirnya konsepsi Movimento tampil lebih dominan menghadapi kenyataan tersebut.

Tindak lanjut dari rencana dekolonisasi pemerintah Portugis di Timor Portugis, Gubernur Kolonel Alves Aldeia pada tanggal 8 Mei 1974 mengumumkan diperbolehkannya masyarakat Timor Portugis mendirikan partai politik (Tanudirjo dkk., 2011: 525). Partai yang pertama kali muncul adalah Uniao Democratica Timorense atau UDT (Uni Demokratik Timor) yang secara resmi diumumkan pada tanggal 11 Mei 1974. Partai ini diketuai oleh Franciscus Lopez da Cruz. UDT menginginkan kemerdekaan Timor-Timur yang diraih secara bertahap. Dimana kemerdekaan akan diraih setelah satu tahun bergabung dalam federasi dengan Portugis (Lapian dan Chaniago, 1988: 28). Partai yang kedua adalah Associacao Social Democratica Timorense atau ASDT (Perkumpulan Sosial Demokratik Timor) yang didirikan pada 20 Mei 1974. Partai ini kemudian diubah namanya menjadi Frente Revolucionaria de Timor-Leste Independente (Front Revolusioner untuk Kemerdekaan Timor) yang lebih dikenal dengan nama Fretilin. Fretilin diketuai oleh Francisco Xavier de Amaral. Partai ini menginginkan terwujudnya kemerdekaan di Timor Timur dengan cepat. Partai yang ketiga adalah Associacao Popular Democratica de Timor (Apodeti) atau Perhimpunan Demokrasi Rakyat Timor yang berdiri pada tanggal 27 Mei 1974 yang diketuai oleh Arnaldo dos Reis Araujo. Partai keempat adalah Trabalhista yang didirikan pada bulan Oktober 1974, berasal dari kaum buruh dan diketuai oleh A. Abrao dan Domingos Pereira. Tujuan pokok dari partai ini adalah memerdekakan Timor Timur, lalu menjadikan Timor-timur sebagai anggota dari Commonwealth. Partai yang terakhir adalah Klibur Oan Timor Aswain (KOTA) yang diketuai oleh Jose Martins. Partai ini didirikan pada tanggal 10 November 1974. Pada mulanya, KOTA berkeinginan untuk menempatkan para liurai di lapis pimpinan rakyat Timor Timur karena mereka dipilih melalui musyawarah sesuai dengan adat kultural yang telah tertanam sejak lama, tetapi kemudian posisi ini telah mengalami pergeseran (Cruz,1999: 36-38),

Sejak partai-partai ini berdiri, terutama partai UDT, Fretilin, dan Apodeti berusaha untuk menunjukkan eksistensinya, mereka saling bersaing untuk mendapatkan dukungan massa. Sedangkan Partai Apodeti pada 31 Agustus 1974, menyatakan bahwa partainya telah mengusulkan agar Timor Portugis menjadi provinsi bagian dari Indonesia (Subroto, 1997: 21). Partai KOTA dan Trabhalista tidak terlalu mengambil bagian dalam persaingan tersebut. Sedangkan ke luar, mereka sibuk mengirim utusan ke berbagai negara, khususnya kepada kedua tetangga terdekat, Indonesia dan Australia. Persaingan antara dua partai UDT dan Fretelin pada akhirnya menjurus kepada kekerasan fisik.

Pada tanggal 27 Juli 1974 pemerintah Portugis mengeluarkan UU No.7/1974 yang substansinya memberikan kesempatan dan mengakui kemerdekaan wilayah-wilayah jajahan Portugis. Keseriusan Portugis untuk dekolonisasi ini dengan mengajukan sebuah memorandum ke PBB yang mengakui penentuan nasib sendiri dan kemerdekaan bagi daerah jajahannya. Sebaliknya, Portugis mengeluarkan pernyataan yang berbeda kepada Timor Portugis. Lewat Menteri Koordinator Antar Wilayah, António de Almeida Santos pada tanggal 3 Agustus 1974 menyatakan keberatan dengan kemerdekaan dan menawarkan federasi kepada Timor Portugis. Pernyataan seirama juga diungkapkan pada tanggal 16 Oktober 1974 saat tiba di Bandara Halim Perdanakusumah dalam perjalanan ke Australia dan Dili. António de Almeida Santos menyatakan bahwa negara Timor yang merdeka dan berdiri sendiri tidaklah realistis. Menurutnya, kemerdekaan politik haruslah didukung oleh kekuatan ekonomi. Hal 
itu kurang dimiliki oleh Timor. Karena itu tidak ada, maka akan mengundang negara lain untuk menjadi penguasa baru (Lapian A. B dan Chaniago, 1988: 34).

Tawaran federasi oleh Portugis ditentang oleh partai-partai, hal inilah yang membuat Timor Portugis mulai bergejolak. Kondisi ini diperburuk dengan perbedaan pandangan politik antara partaipartai sudah begitu mendalam, sehingga mereka bersaing untuk memperjuangkan kepentingan partai masing-masing. Misalnya antara UDT dengan ASDT dimana mereka menghendaki kemerdekaan dengan cara yang berbeda. ASDT/Fretelin menghendaki kemerdekaan sesegera mungkin sementara UDT mengingkan agar proses dekolonisasi melalui proses yang lebih mantap. Perbedaan yang menyolok dari kedua partai di atas terletak pada ideologi militan di kedua belah pihak yang secara ekstrim saling menuduh, dimana UDT dituduh sebagai fasis sedangkan Fretelin dituduh sebagai komunis.

Hal inilah yang menyebabkan kedua partai yang pada awalnya berkoalisi pada 20 Januari 1975, kemudian koalisi itu pecah pada 11 Agustus 1975. Akibat pecahnya koalisi ini, meningkatnya eskalasi persaingan yang menjurus ke konfrontasi senjata. Sedangkan Apodeti berdasarkan pernyataan pada tanggal 31 Agustus 1974 bahwa mereka memilih berintegrasi dengan Indonesia. Apodeti merupakan "pintu" bagi Indonesia untuk terlibat dalam masalah Timor Portugis. Keterlibatan Indonesia yang didukung negara-negara Barat (Amerika dan Australia) merupakan kesulitan tersendiri bagi Portugis hal ini dapat dilihat dari pertemuan-pertemuan antara kedua pemerintahan.

Kebijakan pemerintah Portugal tentang dekolonisasi Timor Timur mulai dilaksanakan ketika Kolonel Lemos Pires menjabat sebagai gubernur baru di Timor Portugis pada 25 November 1974 dengan membawa dua mayor sebagai bawahannya, yaitu Francisco Mota dan Costa Jonatas yang mempunyai jabatan penting sebagai penanggung jawab bidang politik dan media massa (Tanudirjo dkk, 2011: 526). Pejabat lain yang diangkat oleh Pires adalah Mayor Berento sebagai Kepala Staf, Kapten Ramos sebagai perwira intelijen, dan Mayor Coelho sebagai Chief Cabinet.

Di daerah koloni Pires berhadapan dengan berbagai masalah terutama hilangnya moral tentara dan sulit menemukan kosep dekolonisasi yang jelas. Masalah moral tentara dapat dilihat dari latarbelakang pecahnya Revolusi Bunga yang bersumber dari ketidakpuasan tentara terhadap kebijakan pemerintah pusat di Portugal. Tentara Portugis sebagaian besar dari mereka berkeinginan kembali ke tanah airnya sedangkan mereka yang berasal dari Timor Portugis memperlihatkan ketidaksetiaannya. Di sisi lain, kehadiran Lemos di Timor Portugis tidak ada petunjuk yang jelas dari Portugal sehingga tidak memiliki konsep yang jelas tentang dekolonisasi. Hal ini diungkapkan Anwar, dkk., (2003: 22) bahwa...Portugal tidak mempunyai kesatuan konsep yang pasti, hal ini mengakibatkan janji-janji untuk mengembalikan hak-hak sipil dan demokrasi, serta kebebasan membentuk partai politik di Timor-timur tidak sepenuhnya dapat dijalankan. Kesulitan lain yang dihadapi Lemos, perbedaan garis politik di antara partai-partai yang ada sudah begitu mendalam sehingga kesulitan untuk duduk bersama untuk mencarikan solusi permasalahan yang ada.

Pada bulan Mei 1975 Lemos Pires menggagas pertemuan Macao dengan maksud membentuk sebuah komisi untuk Dekolonisasi Timor (Comissão de Descolonização de Timor, CDT), Fretelin tidak hadir dalam pertemuan tersebut. Fretilin curiga bahwa pertemuan tersebut merupakan bagian dari strategi Portugis untuk menyerahkan Timor Portugis kepada Indonesia. Salah satu hasil pertemuan Macao hanyalah menentukan ancar-ancar pelaksanaan referendum sekitar bulan Oktober 1976 dan dua tahun setelah pelaksanaan referendum Portugal akan meninggalkan Timor.

Paska pertemuan Macau yang dilaksanakan pada tanggal 26-28 Agustus 1975, kondisi Timor Portugis makin panas. Pada tanggal 11 Agustus 1975 UDT melancarkan kudeta untuk mengambil alih Dili melalui Movimento Revolucionario Anti-Comunista (Gerakan Revolusioner Anti-Komunis) dengan sasaran orang-orang Fretilin dan pejabat-pejabat Portugal yang dipandang berhaluan komunis (Cruz, 
1999: 69). Fretilin berhasil didesak ke luar oleh lawan politiknya dari kota Dili. UDT berhasil merebut dan menguasai tempat-tempat penting di Dili seperti kantor pos, telepon-telegram, statisun radio, dan sejumlah pos militer dan polisi. UDT juga dapat menguasai lapangan terbang Dili, dan menutupnya untuk kegiatan penerbangan internasional, UDT menahan sejumlah tokoh Fretilin (Lapian A. B dan Chaniago, 1988: 51).

Setelah melakukan konsolidasi dan mendapat bantuan senjata dari kalangan militer Portugis, Fretelin kemudian melakukan serangan balik pada tanggal 20 Asustus 1975. Kota Dili jatuh ke tangan Fretelin yang diikuti kota-kota lain seperti Liquica, Batugede, Maliana, Suai, yang semula menjadi basis UDT. Hal ini menyebabkan arus pengungsi melewati perbatasan Indonesia-Timor Portugis. Dampaknya, Gubernur Timor Portugis menyingkir ke pulau Atauro pada tanggal 26 Agustus 1975, menandai berakhirnya kekuasaan atas Timor Portugis secara de facto. Tindakan Pemerintah Portugal semakin memperburuk keadaan di Timor Portugis sehingga meningkatkan konflik antar partai dan elit lokal setempat.

Pada tanggal 28 November 1975 Fretilin memproklamasikan kemerdekaan Timor Portugis dan berdirinya sebuah Republik Demokrasi Timor Leste (Araujo, 2014: 31). Pernyataan kemerdekaan yang dilakukan oleh Fretilin atas Timor Portugis tidak mendapat pengakuan dari negara-negara barat seperti, Amerika Serikat, dan Australia. Australia melalui Menteri luar negerinya Andrew Peacok, dalam wawancaranya pada tanggal 16 Desember 1975, menjelaskan bahwa Australia tidak mendukung Fretilin dan tidak akan pernah mengakui proklamasi kemerdekaan Timor Timur yang dilakukan secara sepihak oleh Fretilin pada tanggal 28 November 1975 (Soekanto, 1976: 426). Dua hari sesudahnya, sebagai upaya untuk mengimbangi proklamasi kemerdekaan Fretilin, koalisi partai UDT, Apodeti, KOTA dan Trabalhista mengeluarkan deklarasi untuk berintegrasi dengan Indonesia pada tanggal 30 November 1975 di Balibo. Deklarasi itu adalah pernyataan kesepakatan empat partai untuk bergabung dengan Indonesia.

\section{Keterlibatan Indonesia dalam Proses Dekolonisasi}

Pada waktu yang bersamaan, situasi politik global diwarnai perang dingin antara blok Komunisme-Sosialisme di bawah pimpinan Uni Soviet dengan blok Kapitalis-Liberal di bawah pimpinan Amerika Serikat. Kerisauan Amerika Serikat disebabkan kekalahannya terhadap pasukan Vietnam Utara (Komunis) dan kejatuhan Kamboja serta Laos ke tangan pemerintah komunis pada 1975. Untuk membendung meluasnya komunisme di Asia Tenggara, Amerika Serikat dan Australia mendorong Indonesia untuk terlibat langsung di Timor Portugis. Dukungan dari Australia dapat dilihat pada pertemuan antara Presiden Soeharto dengan PM. Australia Gough Whitlam di Wonosobo pada tanggal 6 September 1974 dan di Townsville, Queensland pada tanggal 4 April 1975. Dalam pertemuan tersebut Whitlam mengatakan kepada Soeharto bahwa Timor Portugis seharusnya menjadi bagian dari Indonesia.

Dukungan dari negara-negara Barat juga datang dengan pertimbangan bahwa Indonesia anti komunis dimana pada tahun 1965 Soeharto berhasil menumpas PKI. Pertimbangan lainnya adalah posisi Indonesia dalam Gerakan Non-Blok, OKI maupun ASEAN. Aspek geografis, Indonesia berbatasan langsung dengan Timor Portugis. Indonesia membutuhkan stabilitas kawasan dalam rangka pembangunan. Hal ini dapat dipahami ketika terjadi perang sipil di Timor Portugis, para pengungsi melintasi batas kedua negara dan Indonesia terpaksa mengeluarkan biaya.

Amerika Serikat juga sudah berencana untuk mendekati Indonesia dalam urusan minyak bumi sejak Agustus tahun 1950. Pertimbangan ini dilakukan apabila terjadi perang antara Amerika Serikat dengan Uni Soviet, maka wilayah Timur Tengah tidak berguna untuk Amerika Serikat, sehingga atas usul James E. Webb, Wakil Menteri Luar Negeri Amerika Serikat kepada Menteri Pertahanan Amerika, Johnson untuk sebisa mungkin mendekati Indonesia (Bradley dan Mochtar Lubis, 199: 165). Dukungan AS terhadap Indonesia misalnya dalam kunjungan Presiden Soeharto ke AS pada tanggal 5 
Juli 1975. Dalam pertemuan di Camp David, Soeharto menggariskan kebijakan Indonesia bahwa sebuah Timor Portugis merdeka tidak akan dapat berjalan, dan bahwa akan sulit bagi Portugal untuk bisa terus menjalankan negara ini karena keterpencilannya dari wilayah itu. Kunjungan Soeharto dibalas oleh Presiden AS dengan berkunjung ke Jakarta pada tanggal 6 Desember 1975, sehari sebelum dilancarkannya Operasi Seroja.

Dalam rangka integrasi Timor Portugis, Indonesia dan Portugis mengadakan pertemuan penjajakan antara Menteri Luar Negeri Adam Malik dengan Menteri Luar Negeri Portugal Mario Soares tanggal 21 September 1974 di PBB (Soekanto, 1976: 146). Kesimpulan yang diperoleh dari pertemuan kedua Menteri Luar Negeri itu memberikan peluang baru dimana keduanya akan mengadakan kerjasama dan konsultasi dalam rangka penentuan nasib sendiri Timor Portugis; bahwa hubungan diplomatik perlu dipulihkan sehingga konsultasi antara kedua belah pihak dapat lebih mudah dilakukan; sebelum pemulihan hubungan diplomatik itu dapat direalisasi; maka disepakati bahwa kedua kepala perwakilan tetap kedua negara di PBB dipakai mewakili kedua menteri luar negeri. Disinggung juga kemungkinan dikirimnya seorang utusan khusus Presiden Republik Indonesia yang akan datang ke Lisabon untuk menjelaskan bagaimana sikap Indonesia terhadap Timor (Lapian A. B dan Chaniago, 1988: 30).

Sikap Indonesia berkaitan dengan Timor Portugis disampaikan dalam Sidang Dewan Stabilitas Politik dan Keamanan PBB yang diadakan pada tanggal 8 Oktober 1974. Dalam kesempatan itu, Indonesia menyampaikan tiga sikap: (a) Bahwa Indonesia tidak mempunyai ambisi teritorial; (b) Bahwa Indonesia menghormati hak rakyat Timor Portugis untuk menentuk.an nasibnya sendiri; (c) Bila rakyat Timor Portugis ingin bergabung dengan Indonesia, maka penggabungan itu tidak bisa dilakuk.an atas dua negara, tetapi Timor Portugis harus menjadi bagian dari wilayah negara kesatuan Republik Indonesia (Lapian A. B dan Chaniago, 1988: 30).

Setelah itu, Indonesia mengadakan pertemuan bilateral dengan Portugas pada 14 Oktober 1974. Dalam pertemuan tersebut dibicarakan kemungkinan-kemungkinan masa depan Timor Portugis setelah referendum. Hasil pertemuan bilateral di atas dapat disimpuklan beberapa hal antara lain dimana Portugal dapat mengerti posisi dan sikap Indonesia tentang Timor; khususnya jika dilihat dari sudut masa depan rakyat Timor dan stabilisasi kawasan sekitarnya, dan; kedua belah pihak menyadari perlunya kerjasama antara kedua pemerintah dalam menyelesaikan masa depan Timor Portugis.

Keseriusan Portugal menyelesaikan masalah Timor Portugis dengan mengirim Menteri Seberang Lautan Antonio de Almeida Santos ke Indonesia pada tanggal 16 Oktober 1974. Namun, Portugis cenderung memiliki sikap yang berbeda-beda dan membingungkan Indonesia. Di Bandara Halim Perdanakusumah menyatakan bahwa kemerdekaan bagi Timor Portugis tidak realistis tetapi di Dili ia mengeluarkan pernyataan lagi bahwa di Timor Portugis akan dibentuk dewan Konstituante yang kemudian diadakan referemdum, padahal Indonesia dan Portugis belum pernah membicarakan masalah Dewan Konstituante.

Pertemuan London pada tanggal 9 Maret 1975, pada awalnya pembicaraan berjalan cukup alot dimana Portugal tidak bersedia menyerahkan kedaulatannya atas Timor kepada Indonesia dan meminta kepada Indonesia untuk memahami rencana dekolonisasi yang akan dilaksanakan Portugal di Timor. Dalam pertemuan London juga disepakati pertemuan lanjutan di Macau. Kesulitan yang dihadapi hasil pertemuan London adalah mempertemukan kembali beberapa partai yang saling tertarung. Kesulitan tersebut dapat dilihat dari ketidakhadiran Fretelin di dalam pertemuan di Macau pada tanggal 26-28 Juni 1975. Hal ini disebabkan kecurigaan Fretelin dimana pertemuan tersebut sebagai strategi Portugis menyerahkan Timor Portugis kepada Indonesia.

Dalam rangka memperoleh dukungan Internasional dalam kaitannya dengan masalah Timor Portugis, Indonesia juga membangun komunikasi juga dengan Australia. Presiden Soeharto mengadakan pertemuan dengan Perdana Menteri Australia Gough Whitlam di Townsville, 
Queensland pada tanggal 4 April 1975. Dalam peretemuan tersebut Whitlam memberikan jalan kepada Indonesia agar Timor Portugis bergabung dengan Indonesia. Whitlam meyakini Soeharto bahwa Timor Portugis tidak akan bisa bertahan sebagai negara merdeka serta akan menjadi mangsa bagi negaranegara besar seperti Uni Soviet dan Cina. Hal ini bisa dipahami kekalahan Barat (AS) dalam perang Vietnam yang dibantu Uni Soviet dan Cina yang menyebabkan runtuhnya pemerintahan pro-Barat. Dalam hal ini Indonesia dipandang sebagai komponen yang penting dari strategi pasca-Vietnamnya untuk mencegah penyebaran komunisme lebih lanjut.

Sementara pembicaraan dengan Portugal belum memberikan hasil yang memuaskan, di Timor Portugis terjadi perkembangan baru yang menyebabkan situasi makin tidak menentu. Koalisi yang dibentuk UDT dan Fretelin pecah pada 11 Agustus 1975. UDT mengeluarkan komunike resmi yang membatalkan secara sepihak koalisinya dengan Fretilin. Pertimbangan yang diberikan dalam membatalkan koalisi itu adalah bahwa dasar-dasar kerjasama yang termuat dalam dokumen pokok secara sistimatis dan licik telah disalahgunakan dengan terang-terangan, dari agresi ideologi ke agresi fisik, hingga menimbulkan gangguan keamanan bagi rakyat (Lapian A. B dan Chaniago, 1988: 46). Setelah pecah koalisi antara kedua partai saling menyerang dan mengembangkan kemampuan paramiliternya, mereka telah sampai pada tahap persiapan konfrontasi senjata. Pertikaian bersenjata antara kelompok yang berbeda itu tidak dapat dihindari.

Aksi UDT makin meningkat dengan melancarkan Movimento Revolucionario Anti Comunista (MRAC) atau Gerakan Revolusioner anti Komunis tanggal 11 Agustus 1975. UDT merebut beberapa instalasi penting seperti fasilitas militer, markas polisi, pelabuhan, bandar udara dan fasilitas radio dan telepon di Dili. Aksi UDT dengan cepat menyebar ke seluruh menjuru negeri. UDT juga menahan beberapa pemimpin dan ratusan anggota Fretelin di Palapaço, Dili. Pada minggu pertama UDT masih menunjukan kehebatannya di lain pihak Fretelin mulai menyusun kekuatan sehingga pada 20 Agustus 1975 melancarkan serangan bersenjata di bawah pimpinan Rogerio Labato dan Hermenegildo Alves. Fretelin berhasil mengambil alih Quartel markas tentara di Taibessi sehingga pada 22 Agustus kota Dili dapat dikuasai kembali. Kondisi ini menyebabkan Gubernur Timor Portugis pada pagi hari tanggal 25 Agustus, meninggalkan daratan pulau Timor dan menyeberang ke Pulau Atauro. Dampaknya, gubernur kehilangan kepercayaan dari masyarakat dan partai politik.

Awal September 1975, Fretilin sudah mulai mengambil alih peranan. Di berbagai front, pasukan UDT dilumpuhkan sehingga memasuki minggu kedua bulan September 1975 hampir sebagian besar wilayah Timor Timur sudah dikuasai Fretilin. Kondisi ini memaksa UDT, Apodeti, Klibur Oan Timor Aswain (KOTA) dan Trabalhista mengungsi ke daerah perbatasan Batugade, dan kemudian melintasi perbatasan ke Timor Barat. Menurut Panglima Kodam XVI/Udayana, pada tanggal 11 September 1975 jumlah pengungsi sudah mencapai 27.858 orang suku Timor dan 489 orang warga negara asing di Atambua dan daerah sekitarnya (Soekanto, 1976: 246).

Dalam rangka menyelesaikan masalah Timor Portugis, Indonesia mengadakan pertemuan dengan Portugal. Pada tanggal 2-3 Nopember 1975 diadakan pertemuan antara Portugal yang diwakili Menlu Portugal Artunes sedangkan Indonesia diwakili Menlu Adam Malik. Namun, pertemuan di Roma tidak membawa hasil yang memuaskan lebih-lebih setelah aksi sepihak Komite Sentral Fretelin menjawab komunike di atas pada tanggal 28 Nopember 1975 mencetuskan proklamasi kemerdekaan sepihak di Dili dengan membentuk Republik Demokrasi Timor yang disusul dengan pengumuman nama-nama kabinet. Pernyataan proklamasi Fretelin tidak mendapatkan pengakuan dari negera-negara besar kecuali beberapa negara di Afrika bekas jajahan Portugis yang tidak memiliki pengaruh di atas panggung politik internasional.

Didorong oleh keadaan yang terdesak tokoh-tokoh keempat partai mulai membicarakan kemungkinan bergabung ke Indonesia. Untuk membangun komunikasi dengan Indonesia, Lopes da Cruz intensif melakukan kunjungan ke Indonesia. Hasilnya, tanggal 7 September 1975, di Batugade, 
para pemimpin UDT, KOTA, dan Trabalhista mengeluarkan komunike bersama yang ditujukan pada Presiden Soeharto agar Timor Portugis untuk diintegrasikan dengan Indonesia. Pembicaraan ini diiringi penyusupan bersenjata ke wilayah Timor Portugis dan 15 Oktober 1975 mulai melakukan serangan batalyon-batalyon dari Brigade Infantri Kedua ABRI melancarkan serangan ke Balibó sehingga tanggal 16 Oktober, ketika militer Indonesia menguasai Balibo dan Maliana. Fretilin pindah ke Atabae dan Bobonaro dan beberapa langkah lagi akan menguasai kota Dili. Menyadari kedudukannya yang semakin terdesak, pada tanggal 24 November 1975 Fretilin meminta bantuan kepada PBB agar Indonesia menarik mundur pasukannya dari Timor Timur (Gunn, 2005: 420).

Di lain pihak, empat partai pada tanggal 30 Nopember 1975 mendeklarasikan apa yang disebut Proklamasi Balibo yang subtansi keempat partai di atas bergabung dengan Indonesia. Pada tanggal 4 Desember 1975, Indonesia lewat Menteri Penerangan Mashuri mengeluarkan pernyataan resmi bahwa Pemerintah Indonesia menghargai hak bersumpah, dan memahami sedalam-dalamnya pernyataan empat partai menyatukan diri ke dalam Negara Republik Indonesia.

Pada bagian akhir isi proklamasi Balibo dinyatakan "Berkenaan dengan isi Proklamasi integrasi ini, pemerintah dan rakyat Indonesia diharapkan untuk mengambil langkah-langkah yang diperlukan akan melindungi kehidupan rakyat yang sekarang menempatkan dirinya sebagai bagian dari rakyat Indonesia, namun yang masih hidup di bawah teror dan praktek fasis Fretilin yang dibenarkan oleh Pemerintah Portugal" (Tomodok, 1994: 309).

Berdasarkan isi deklarasi Baibo maka pihak Indonesia mengambil langkah-langkah penting. Pada tanggal 6 Desember 1975, Presiden Soeharto menerima kunjungan Presiden AS Gerald Rudolph Ford. Hal ini tidak dapat dipungkiri bahwa Amerika Serikat beserta sekutunya memang mempunyai pengaruh yang besar bagi Indonesia terutama dalam urusan keamanan dan militer internasional, karena ketergantungan Indonesia pada mitra-mitra Baratnya untuk peralatan militer (Nevins, 2008: 26).

Berdasarkan permintaan tersebut, pemerintah Indonesia mengeluarkan kebijakan melalui Surat Keputusan Menhankam Pangab Nomor: Skep/1063/VIII/1975 tanggal 31 Agustus 1975 dengan dibentuk Komando Tugas Gabungan (Kogasgab) dengan nama sandi Operasi Seroja. Kogasgab mempunyai tugas pokok melaksanakan operasi militer strategis dalam rangka pemeliharaan dan pemantapan stabilitas nasional (Hamam dkk, 2005: 97). Operasi ini melibatkan hampir 10.000 tentara. Dalam operasi ini, pasukan Kopassanda bersama pasukan dari divisi Brawijaya dan Siliwangi mendarat di Dili. Pendaratan itu dipimpin oleh Jenderal L.B. Moerdani dan Brigjen Dading Kalbuadi (Subroto, 1996: 116). Pasukan Fretilin semakin terdesak dan kemudian meninggalkan kota Dili dengan bergerilya di daerah pegunungan.

Dalam Kabinet Paripurna yang dilaksanakan pada tanggal 29 Juni 1976, yang dipimpin oleh Presiden Soeharto memutuskan untuk menanggapi secara positif keinginan Rakyat Timor Timur dengan segera melaksanakan proses integrasi wilayah itu ke dalam Indonesia. Rancangan UndangUndang (RUU) tentang penggabungan Timor Timur ke wilayah Indonesia pun diajukan kepada DPRRI pada tanggal 1 Juli 1976. RUU tersebut disahkan menjadi Undang-Undang tentang Penyatuan Timor Timur ke dalam Negara Republik Indonesia Tingkat I Timor Timur. Kemudian pada tanggal 17 Juli 1976, Presiden Soeharto menandatangani Undang- Undang No.7 Tahun 1976 yang menyatakan bahwa Timor Timur adalah bagian dari Indonesia dan secara resmi menetapkan daerah tersebut sebagai Propinsi Daerah Tingkat I yang ke-27 dari NKRI (Noor, 1977: 23). Undang-Undang tersebut kemudian disahkan melalui TAP MPR No. VI/1978.

\section{Kesimpulan}

Proses dekolonisasi Timur Portugis dilatarbelakangi meletusnya revolusi Bunga di Portugal pada tanggal 25 April 1974 yang dikenal dengan Revolusi Bunga "Carnation Revolution" atau "Revolusi 
Anyelir”. P aska kudeta terjadi perbedaan pandangan tentang konsep dekolonisasi terhadap kononikoloni Portugis baik di Afrika maupun di Asia. Perbedaan pendapat tersebut menyebabkan tidak adanya kesatuan dan kejelasan konsep tentang proses dekolonisasi di Timor Portugis. Spínola dengan konsep dekolonisasi yaitu negara federal yang memiliki otonomi intern secara penuh sementara pemerintah federal di Lisabon akan menguasai pertahanan dan hubungan luar negeri sedangkan pada umumnya masyarakat menghendaki agar Portugis mundur dari seluruh wilayah jajahan termasuk Timor Portugis. Ketidakjelasan konsepsi Movimento dalam rangka dekolonisasi Timor Portugis dimana Gubernur Kolonel Alves Aldeia mengumumkan diperbolehkannya mendirikan partai politik yang kemudian saling bersaing secara politik bahkan pertikaian senjata yang menyebabkan kekacauan di Timor Portugis.

Keterlibatan Indonesia dalam proses dekolonisasi di Timor Portugis dilatarbelakangi oleh dua faktor. Pertama, kondisi politik internasional dimana sedang berlangsung saat perang dingin antara blok Barat dengan blok Timur. Paska kemenangan komunis di Vietnam, negara-negara Barat mengkhawatirkan Timor Portugis akan mendapat pengaruh dari Cina maupun Uni Soviet. Oleh karena itu bangsa-bangsa Barat mendorong Indonesia mengambil-alih Timor Portugis. Dukungan negara-negara Barat misalnya dalam kunjungan Presiden Soeharto ke AS pada tanggal 5 Juli 1975. Dalam pertemuan tersenut Soeharto menjelaskan kebijakan Indonesia terhadap Timor Portugis yangkemudian dibalas oleh kunjungan Presiden AS pada tanggal 6 Desember 1975, sehari sebelum dilancarkannya Operasi Seroja. Kedua, adanya keinginan partai politik di Timor Portugis untuk berintegrasi dengan Indonesia.. Apodeti merupakan "pintu" bagi Indonesia untuk terlibat dalam masalah Timor Portugis. "Pintu" itu semakin terbuka dengan adanya deklarasi Balibo pada tanggal 30 November 1975 untuk berintegrasi dengan Indonesia; Ketiga, aspek geografis, Indonesia berbatasan langsung dengan Timor Portugis. Indonesia membutuhkan stabilitas kawasan dalam rangka pembangunan. Hal ini dapat dipahami ketika terjadi perang sipil di Timor Portugis, para pengungsi melintasi batas kedua negara dan Indonesia terpaksa mengeluarkan biaya.

\section{Daftar Pustaka}

Abdullah, Taufik dan Abdurrahman Suryamiharjo. (1985). Ilmu Sejarah dan Historiografi; Adab dan Perspektif. Gramedia: Jakarta.

Abdurrahman, Dudung. (2007). Metodologi Penelitian Sejarah. Jakarta: Logos Wacana Ilmu.

Araujo, Basilio Dias. (2014). Timor Timur Gagalnya Sebuah Diplomasi: Suatu Analisa dan Kritik dari Seorang Pelaku Sejarah. Depok: Indie Publishing.

Bradley, William L. dan Mochtar Lubis. (1991). Dokumen-Dokumen Pilihan Tentang Politik Luar Negeri Amerika Serikat dan Asia. Jakarta: Obor.

Cruz, Fx Lopez da. (1999). Kesaksian: Aku dan Timor Timur. Jakarta: Yayasan Tunas Harapan Timor Lorosae.

Dunn, James, 2003, East Timor: A Rough Passage to Independence, edisi ketiga, Australia: Longueville Media.

Fernandes, Clinton. Tt. Companion to East Timor - Kolonialisme, Kemerdekaan dan Masa Depan TimorLeste, diunduh https://www.unsw.adfa.edu.au/school-of-humanities-and-socialsciences/node/ 268">, pada hari Selasa, 15 Desember 2020 jam:12.55.

Hamam, Widjdan (Kolonel Inf) dkk. (2005). Sejarah TNI AD 1974-1975. Jakarta: Dinas Pembinaan Mental Angkatan Darat.

https://id.wikipedia.org/wiki/Revolusi_5_Oktober_1910"/>, diunduh Rabu 15-01-2020 jam:12.45. 
https://pt.wikipedia.org/wiki/Junta_de_Salva\%C3\%A7\%C3\%A3o_Nacional, diunduh Senin, 30 Nopember 2020, jam 19.15.

https://www.republika.co.id/berita/internasional/selarung-waktu/18/02/01/p3gcj3377-sejarah-hariini-raja-portugis-dan-putranya-tewas-ditembak, diunduh Senin, 30 Nopember 2020, jam 19.15.

Joseph Nevins. (2008). Pembantaian Timor Timur: Horor Masyarakat Internasional. Yogyakarta: Galang Press.

Lapian A. B dan JR. Chaniago. (1988). Timor-timur dalam Gerak Pembangunan. Departemen Pendidikan dan Kebudayaan: Direktorat Jenderal Kebudayaan Direktorat Sejarah dan Nilal-Nilai Tradisional Proyek Invent Arisasi dan Dokumentasi Sejarah Nasional.

Lyons, Martin. (1986). The Totem and the Tricolour: A Short History of New Caledonia since 1774, New South Wales University Press Kensington.

Makarin, Zacky Anwar, dkk. (2003). Hari-Hari Terakhir Timor-Timur: Sebuah Kesaksian. Jakarta: PT. Sportif Media Informasindo.

Neonbasu, P. Groger. (1997). Peta Politik dan Dinamika Pembangunan Timor Timur. Jakarta: Yanense Mitra Sejati.

Nicol, Bill. (1978). Timor: The Stillborn Nation, Visa Books, Melbourne and Connecticut.

Noor, Machmudin. (1997). Lahirnya Timor Timur. Jakarta: Badan Penerbit Almanak RI/ Balai Pustaka.

Sjamsuddin, Helius. (2007). Metodologi Sejarah. Ombak: Yogyakarta.

Soekanto, (1976). Integrasi: Kebulatan Tekad Rakyat Timor Timur. Jakarta: Bumi Restu.

Subroto, Hendro. (1997). Saksi Mata Perjuangan Integrasi Timor Timur. Jakarta: Pustaka Sinar Harapan.

Sugiono. (2013). Metode Penelitian Pendidikan, Pendekatan Kuantitatif, Kualitatif dan R Ë D, ed.18. Bandungh: Alfabeta.

Sulasman. (2004). Metodologi Penelitian Sejarah; Teori, Medode, Contoh Aplikasi. Pustaka Setia: Bandung.

Tanudirjo, Daud Aris dkk. (2011). Indonesia dalam Arus Sejarah. Jilid 8. Jakarta: Ichtiar Baru van Hoeve.

Thomaz, Luís Filipe F. R. (1994). De Ceuta A Timor. Lisabon: Difel.

Wallace, Alfred Russel (1869). Sejarah Nusantara, The Malay Archipelago. Yogyakarta: Indoliterasi.

Wallace, Alfred Russel. (1964). The Malay Archipelago: The Land of the Orang-utan and the Bird of Paradise. London: Dover. 